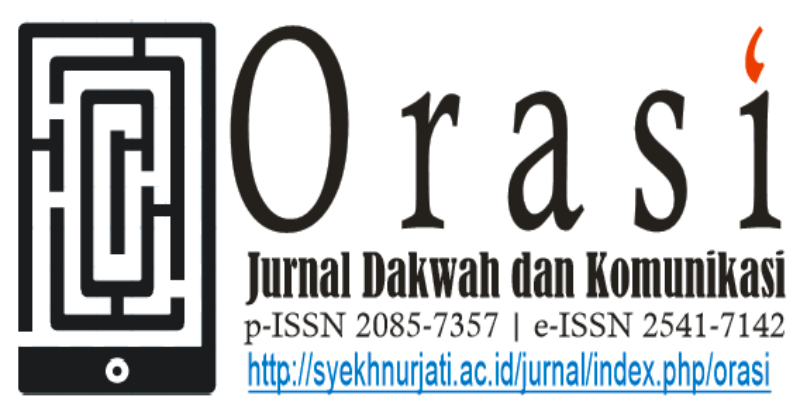

Volume 10 No. 2 Desember 2019

\title{
MEDIA SOSIAL DAN RADIKALISME MAHASISWA
}

\section{SOCIAL MEDIA AND STUDENTS RADICALISM}

\author{
Herman Beni ${ }^{1}$, Arief Rachman ${ }^{2}$ \\ ${ }^{1}$ Program Studi Bimbingan dan Konseling Islam, IAIN Syekh Nurjati Cirebon \\ ${ }^{2}$ Program Studi Komunikasi dan Penyiaran Islam, IAIN Syekh Nurjati Cirebon \\ 'e-mail:herman.beni@syekhnurjat.ac.id \\ 'e-mail:arief.rachman@syekhnurjat.ac.id
}

\begin{abstract}
ABSTRAK
Penelitian ini bertujuan untuk mengidentifikasi potensi dan permasalahan yang dihadapi mahasiswa dan perguruan tinggi dalam mencegah merasuknya paham-paham radikalisme melalui penggunaan media sosial Desain penelitian menggunakan pendekatan mix-methods, yang diawali pendekatan kuantitatif dan dilanjutkan dengan pendekatan kualitatif. Temuan penelitian menunjukkan bahwa ada sejumlah potensi yang belum dimanfaatkan perguruan tinggi dalam mencegah paham radikalisme masuk dalam kehidupan kampus, seperti memanfaatkan masjid kampus sebagai pusat media deradikalisme. Penggunaan media sosial oleh mahasiswa sedikit banyak telah menunjukkan pemanfataannya yang lebih bijak dengan tidak mengakses website-website yang diindikasikan memiliki materi radikalisme. Perguruan tinggi telah berupaya membekali mahasiswa dengan materi deradikalisme sebagai usaha untuk membekali mahasiswa agar dapat terhindar dari uapaya-upaya yang mengarah kepada radikalisme. Output yang dihasilkan menjadi salah satu alternatif untuk penguatan konsep dasar upaya pembekalan pengetahuan, sikap dan perilaku mahasiswa untuk menghindari berbagai pengetahuan, sikap dan perilaku radikal.
\end{abstract}

Kata Kunci: Media Sosial, Radikalisme, Mahasiswa

\begin{abstract}
This study aims to identify the potential and problems faced by students and universities in preventing radicalism from infiltrating through the use of social media. The research design uses a mix-methods approach, which starts with a quantitative approach and continues with a qualitative approach. The research
\end{abstract}

Orasi: Jurnal Dakwah dan Komunikasi | Volume 10, No. 2, Desember 2019 
findings show that there are a number of potentials that have not been utilized by universities in preventing radicalism from entering campus life, such as utilizing campus mosques as a media center for deradicalism. The use of social media by students has more or less demonstrated their wiser use by not accessing websites that are indicated to have material radicalism. Higher education has tried to equip students with deradicalism material in an effort to equip students to avoid attempts that lead to radicalism. The resulting output is an alternative for strengthening the basic concepts of efforts to equip students with knowledge, attitudes and behavior to avoid a variety of radical knowledge, attitudes and behaviors.

Keywords: Social Media, Radicalism, Students

\section{Pendahuluan}

\subsection{Latar Belakang Penelitian}

Fenomena maraknya geliat keagamaan di perguruan tinggi, baik umum maupun agama, tidaklah hadir begitu saja. Sejak reformasi digulirkan di tahun 1998 oleh mahasiswa dan masyarakat telah membawa angin segar dalam perikehidupan sosial bermasyarakat. Termasuk di dalamnya adalah perikehidupan beragama, baik dalam praktek keseharian, pemikiran maupun gerakan keagamaan.

Dalam iklim demokrasi yang sangat masif ini tidaklah heran apabila organisasi yang berlandaskan keagamaan tumbuh subur. Gerakan keagamaan Islam berkembang dengan sangat pesat. Pada masa itu, berbagai organisasi Islam secara tegas mendeklarasikan dirinya sebagai organisasi Islam, seperti Hizbut Tahrir Indonesia (HTI), Front Pembela Islam (FPI, dan juga partai Islam seperti Partai Keadilan Sejahtera (PKS). Selain itu, sejak era tahun 80-an, gairah untuk melaksanakan kegiatan yang bernafaskan Islam semakin masif. Pengajian, Majelis Taklim semakin banyak diminati oleh masyarakat Indoesia guna memenuhi kebutuhan akan siraman rohani. Penerbitan serta publikasi tentang agama Islam, baik melalui media massa maupun media cetak seperti buku, semakin banyak bisa dijumpai di berbagai toko buku. Demikian juga dengan pola berpakaian, semakin banyak umat muslim terutama Muslimah yang secara syar'i menggunakannya di berbagai kesempatan. Arus Islamisasi ini telah menyentuh seluruh sendi-sendi kehidupan manusia di Indonesia. Tidak terkecuali di dunia pendidikan.

Salah satu lembaga pendidikan yang menjadi tempat penyemaian gerakan Islam tersebut adalah perguruan tinggi. Dengan adanya Lembaga Dakwah Kampus (LDK) yang ada di hampir seluruh perguruan tinggi, menjadikan kampus sebagai tempat yang sangat strategis dalam menyemaikan bibit-bibit gerakan Islamisasi pada kalangan mahasiswa. LDK merupakan salah satu organisasi intra kampus yang dimotori oleh kalangan mahasiswa menjadi "kawah candradimuka" bagi aktivis mahasiswa untuk menempa diri dengan proses pembelajaran dan berdakwah. Para senior LDK selalu berupaya 
menyiapkan kader mahasiswa yang berasal dari mahasiswa baru, baik dari internal kampus maupun dari kampus lainnya guna melanjutkan tongkat estafet dalam berdakwah. Dengan melibatkan mahasiswa dari luar kampusnya, maka LDK semakin eksis di berbagai kampus.

Keanggotaan LDK, memiliki karakteristik yang unik, khususnya di Wilayah Cirebon. Banyak anggota LDK merupakan lulusan pondok pesantren yang tersebar di wilayah Cirebon. Sebagai alumni pondok pesantren, ghirah atau semangat untuk berdakwah sangatlah tinggi. Semangat untuk saling berbagai ilmu keagamaan sering kali menjadi ajang untuk menjajal paham-paham baru yang mungkin selama di pondok pesantren tidak mereka dapatkan. Dengan beragamnya pola pendidikan dan materi pengajaran di berbagai pondok, para alumni semakin tertantang untuk mencari dan mendapatkan ilmu keagamaan yang lebih aktual dan lebih beragam tersebut.

Pondok pesantren adalah institusi pendidikan Islam tradisional yang biasanya mengkhususkan diri pada pengajaran Islam. Walaupun demikian, lembaga ini membuka diri untuk mengadopsi sistem pembelajaran mutakhir melalui penambahan pelajaran, khususnya yang terkait dengan ilmu-ilmu pengetahuan non-agama. Sikap terbuka untuk mengadopsi sistem pembelajaran mutakhir ini merupakan cerminan keterbukaan dan kelapangdadaan para Kyai sebagai pemimpin di pondok pesantren. Walau demikian, para Kyai tetap menjaga ciri khas dari sistem pembelajaran tradisional yang telah dilakoninya secara turun temurun. Para Kyai tersebut yakin bahwa perubahan harus dilakukan sebagai respons terhadap tuntutan zaman tanpa merusak aspek-aspek positif dari kehidupan masyarakat khususnya di pondok pesantren.

Lebih lanjut dikatakan bahwa, "karena terjadinya pemboman yang telah menewaskan ratusan warga sipil itu, pesantren menjadi sorotan kembali, Tuduhan sebagai sarang pemberontak yang sekarang berubah menjadi teroris, kembali dialamatkan pada lembaga pendidikan Islam itu" (Turmudi, 2005:132-133). Dengan demikian, keberadaan pondok pesantren yang tersebar di wilayah Cirebon tersebut, dengan para santri yang melanjutkan ke jenjang pendidikan tinggi, perlu upaya untuk mengembalikan citra positif di hadapan masyarakat dengan berupaya membekali para santri dengan pengetahuan tentang radikalisme.

Kampus sebagai lembaga yang menerima mahasiswa dari berbagai latar belakang kehidupan pendidikannya, seyogyanya menjadi pusat transformasi sosial bagi mahasiswa untuk secara kritis menyikapi berbagai situasi dan kondisi masyarakat yang saat ini sedang menghadapi berbagai persoalan. Dengan diawali pemikiran kritis, mahasiswa dapat melanjutkan aksi sosialnya dengan membawa perubahan yang lebih bermakna dan bermanfaat bagi masyarakat. Hal ini akan lebih bermanfaat bagi masyarakat dibandingkan bila mahasiswa menjadi lahan bagi gerakan-gerakan yang dampaknya 
membawa keresahan bagi masyarakat.

Perkembangan penyebaran paham radikalisme di kalangan terpelajar, mahasiswa dan pelajar sudah menunjukkan tingkat penyebaran yang cukup tinggi. Hal ini disampaikan oleh Kepala Badan Intelejen Negara (BIN) Jenderal Pol (Purn) Budi Gunawan, bahwa

“... sekira 39 persen mahasiswa di Tanah Air telah terpapar paham radikal. Bahkan, paham radikal juga dinilai tumbuh subur di lingkungan perguruan tinggi yang tak hanya menyasar kalangan mahasiswa. ... pihaknya tengah melakukan pengamatan penyebaran radikalisme di kalangan kampus. Sejumlah kampus di 15 provinsi di Tanah Air ditengarai menjadi tempat pembasisan calon-calon pelaku teror baru dari kalangan mahasiswa.

Menurut Budi Gunawan hasil survei BIN pada 2017 menyebutkan 39\% mahasiswa dari berbagai PT di Indonesia telah terpapar paham-paham radikal. Sebanyak $24 \%$ mahasiswa dan $23,3 \%$ pelajar tingkat SMA juga setuju dengan jihad, untuk tegaknya negara Islam atau khilafah.

Riset BIN tersebut juga berbanding lurus dengan survei Lembaga Ilmu Pengetahuan Indonesia (LIPI) yang menunjukkan bahwa saat ini radikalisme telah merambah dunia mahasiswa. "Terdapat peningkatan pemahaman konservatif atau fundamentalisme keagamaan yang sejalan dengan hasil survei Mata Air Foundation dan Alvara Research Center.

Di sisi lain, lanjut dia, hasil penyelidikan beberapa kasus teror di Jakarta semakin menegaskan bahwa kampus merupakan target tempat untuk tumbuh dan berkembangnya paham radikal, yang kemudian menghasilkan bibit pelaku terorisme yang baru.

Budi Gunawan mencontohkan Bahrun Naim, pelaku teror bom Sarinah di Jalan MH Thamrin, Jakarta Pusat, Januari 2016. Bahrun Naim, seorang pemuda yang mulai melibatkan diri dalam gerakan radikal sejak ia kuliah di Universitas Sebelas Maret, Surakarta.

Dengan semakin meningkatnya arus radikalisme yang semakin merasuk ke dalam kehidupan kampus seyogyanya mendapat perhatian yang khusus. Pihak kampus seyogyanya memiliki master Plan yang menunjang kepada pengembangan intelektual dan sosial mahasiswanya dengan membekali mahasiswa dengan berbagai kegiatan yang mengembangkan minat dan bakat mereka.

Di sisi lain, kampus juga harus mematangkan potensi mahasiswa dengan berbagai ide, gagasan serta permasalahan yang memiliki solusi pemecahannya. Gagasan dan pemikiran yang diusung harus mendapatkan porsi yang sama agar tidak ada pemikiran 
ataupun gagasan yang mendominasi. Pemikiran tentang ke-Indonesiaan serta pemikiran multikultural dapat disinergikan dengan potensi akademik mahasiswa.

Sebagai alternatif penanganan kasus radikalisme di lingkungan kampus dan masyakat, Budi Gunawan sebagai Kepala BIN memberikan tawaran berupa “...antara lain New Public Management dengan mendorong peningkatan peran masyarakat, mahasiswa dan ormas Islam seperti NU sebagai organisasi Islam terbesar yang memiliki 80 juta orang untuk aktif dalam pengelolaan interaksi sosial di ranah publik untuk menangkal berkembangnya radikalisme, terorisme, dan intoleransi."

Bahkan, menurut Budi Gunawan, dari segi ekonomi kerakyatan pun ditengarai mampu meredam benih radikalisme di kalangan masyarakat sebagaimana dikatakannya sebagai berikut "Termasuk pemberdayaan ekonomi lokal di lingkungan pesantren dan masyarakat melalui UMKM dan koperasi serta penguasaan IPTEK dan informasi dan tentunya bekerjasama terhadap pemerintah mengatasi hal hal untuk melawan intoleransi di negeri ini”

Pada saat yang bersamaan, perkembangan teknologi di era sekarang ini sangatlah pesat. Perkembangan gawai (smartphone) sebagai media komunikasi dengan berbagai aplikasinya membuat kehidupan manusia semakin mudah dan semakin terhubung antara satu individu dengan individu lainnya. Penggunaan gawai sebagai media komunikasi dengan aplikasi networking-nya atau lebih dikenal dengan media sosial semakin memudahkan proses komunikasi antar manusia. Saat ini, dapat kita lihat dengan mudah seseorang menggunakan gawai sebagai sarana komunikasi untuk melakukan berbagai kegiatannya. Salah satunya adalah berbagi informasi.

Kegiatan berbagi informasi menggunakan gawai dengan memanfatkan beberapa aplikasi komunikasi seperti WhatsApp, Telegram, Blackberry Messenger (BBM), Facebook memudahkan pengguna untuk melakukan komunikasi dan berbagi informasi. Penggunaan aplikasi-aplikasi tersebut pada akhirnya menjadi sebuah "kebutuhan" masyarakat untuk melakukan komunikasi dan berbagi informasi, tidak terkecuali mahasiswa.

Mahasiswa sebagai anggota masyarakat ilmiah, menggunakan gawai sebagai media komunikasi. Proses komunikasi yang mereka lakukan untuk mempermudah dan memperlancar proses komunikasi sehingga lebih efektif dan efisien. Saat ini, mahasiswa lebih terbuka berkomunikasi dengan sesama mahasiswa, berkomunikasi dengan staf jurusan atau fakultas serta kepada dosennya. Bahkan dengan menggunakan misal - WhatsApp, mahasiswa bisa membentuk grup (WhatsAppGroup [WAG]) untuk memperlancar proses komunikasi mereka.

Di sisi, lain, keberadaan Group tersebut dapat juga digunakan sebagai sarana untuk menyebarkan ide ataupun konten yang bersifat negatif. Konten pornografi dapat 
dengan mudah tersebar dengan hanya mengklik tombol share maka content tersebut masuk ke dalam sebuah WAG. Selain itu, ide ataupun paham-paham yang kadangkala bertentangan dengan islam pun dengan mudah menyebar dalam WAG tersebut. Paham tersebut, salah satunya adalah paham radikalisme.

Dengan berpijak pada permasalahan tersebut, maka perlu dikaji lebih dalam bagaimana potensi mahasiswa di Cirebon terhadap tumbuhkembangnya paham radikalisme. Selain itu, penting adanya kajian tentang media penyebaran paham radikalisme di kampus dan khususnya di kalangan mahasiswa serta bagaimana lembaga kampus berupaya mengantisipasi dan mereduksi paham radikalisme di kalangan mahasiswanya.

\subsection{Rumusan Masalah}

Penelitian ini lebih menitikberatkan pada penelusuran kondisi nyata di masyarakat akademisi khususnya masyarakat perguruan tinggi terkait dengan kegiatan kemahasiswaan yang ditengarai memiliki kecenderungan telah terkontaminasi oleh paham radikalisme, baik dari segi kuantitas maupun segi kualitas. Segi kuantitas akan menelusuri keberadaan berbagai sarana dan prasarana serta aspek demografis mahasiswa. Sedangkan segi kualitas akan menelusuri permasalahan munculnya benih-benih radikalisme yang ada dan berkembang serta upaya penyelesaian permasalahan radikalisme tersebut.

\subsection{Pertanyaan Penelitian}

Dengan menyimak latar belakang masalah dan rumusan masalah, maka penelitian ini mencoba menjawab pertanyaan penelitian sebagai berikut :

- Bagaimana komposisi demografis mahasiswa sebagai komunikan dari penyebaran paham radikalisme?

- Bagaimana pola penggunaan sarana atau media penyebaran paham radikalisme?

\subsection{Tujuan dan Manfaat Penelitian}

\section{Tujuan Penelitian}

Berdasarkan pertanyaan penelitian tersebut, penelitian yang akan dilaksanakan bertujuan untuk

- Untuk mendapatkan gambaran yang komprehensif mengenai komposisi demografis mahasiswa sebagai komunikan dari penyebaran paham radikalisme

- Untuk memetakan penggunaan sarana atau media penyebaran paham radikalisme

\section{Manfaat Penelitian}

- Manfaat Akademik

Dapat menambah wawasan serta memperkaya khazanah intelektual bagi peneliti dan pembaca dalam kajian radikalisme di lingkungan perguruan tinggi khususnya di kalangan mahasiswa.

- Manfaat Praktis

Penelitian ini diharapkan dapat berguna untuk pemerhati proses penyebaran paham-paham 
radikalisme di perguruan tinggi khususnya di kalangan mahasiswa serta mencoba menawarkan alternatif solusi bagi upaya mengantisipasi atau bahkan mereduksi penyebaran paham-paham radikalisme di perguruan tinggi khususnya di kalangan mahasiswa di wilayah Cirebon.

\subsection{Penelitian Relevan}

Penelitian yang berjudul "Radikalisme Islam di Kalangan Mahasiswa Perguruan Tinggi Negeri di Banjarmasin" diketuai oleh Prof. Dr. H. Akhmad Fauzi Aseri, MA dengan anggota Drs. Bayani Dahlan, M.Ag dan Mariatul Asiah, MA merupakan penelitian yang dijadikan sebagai referensi utama bagi pelaksanaan penelitian yang akan dilaksanakan oleh tim peneliti di Cirebon. Penelitian yang dilaksanakan di Banjarmasin dengan melibatkan tiga perguruan tinggi negeri yaitu IAIN Antasari Banjarmasin, Universitas Lambung Mangkurat (Unlam) dan Politeknik Banjarmasin (Poliban) dilaksanakan pada tahun 2014. Penelitian yang dilatarbelakangi oleh maraknya arus radikalisme yang menimbulkan kekhawatiran jika melihat realitas bangsa Indonesia yang penuh keragaman...mau tidak mau harus melihat pada peranan dan fungsi yang dapat dimainkan pendidikan khusunya pendidikan Islam dalam penyemaian sikap keberagaman yang menghargai multikulturalistik dan pluralistik masyarakat (Aseri, 2016:9).

Penelitian ini mengungkap pandangan aktivis mahasiswa serta peran institusi dalam pencegahan radikalisme di kalangan aktivis mahasiswa di ketiga perguruan tinggi negeri yang ada di Banjarmasin. Adapun metode yang digunakannya adalah metode kualitatif dan bersifat deskriptif. Nara sumber penelitian ini adalah kalangan aktivis mahasiswa berdasarkan posisi mereka dalam kepengurusan DEMA dengan prioritasnya adalah ketua, sekretaris serta ketua bidang masing-masing organisasi tersebut serta ketua (Lembaga Dakwah Kampus (LDK). Pengumpulan data dengan cara observasi dan wawancara serta telaah sumber serta dokumenter. Data yang terkumpul dianalisis dengan teknik deskriptif kualitatif (Aseri, 2016:16-17).

\subsection{Kerangka Konsep}

\section{Komunikasi}

Istilah komunikasi menurut asal katanya berasal dari bahasa Latin communicatio, atau bisa juga berasal dari kata communis atau dalam bahasa Inggris common, commones, communication (Effendy, 2008: 3). Yang berarti pemberitahuan, pemberian bagian (dalam sesuatu), dan atau pertukaran. Komunikasi merupakan penyampaian pesan dari komunikator kepada komunikan. Miller (1995) memaknai komunikasi sebagai proses berlalunya suatu informasi dari satu tempat ke tempat lainnya (Santoso \& Setiansah, 2010). Sementara Hampton (dalam Moekijat, 1993), menyatakan bahwa "Communication is the process by which people at work in organizations transmit information to another and interpret its meaning”. Dimana komunikasi merupakan proses melalui mana 
orang-orang yang sedang bekerja dalam organisasi menyampaikan informasi yang satu kepada yang lain dan menafsirkan maksudnya. Carl I. Hovland menegaskan bahwa, "communication is the process to modify the behaviour of otherindividuals". Dimana komunikasi dalam prosesnya dapat mengubah perilaku orang lain. (dalam Effendy,2006:10).

\section{Dakwah}

Dakwah secara etimologis berasal dari bahasa Arab "da'wah"da'wah mempunyai tiga huruf asal, yaitu dal, 'ain dan wawu.Dari ketiga huruf asal ini, terbentuk beberapa kata dengan ragam makna. Makna-makna tersebut adalah memanggil, mengundang, minta tolong, meminta, memohon, menanamkan, menyuruh datang, mendorong, menyebabkan, mendatangkan, mendoakan, menangisi dan meratapi (Aziz Ali, 2004 : 6).

Dakwah adalah kegiatan komunikasi, akan tetapi kegiatan komunikasi belum tentu merupakan kegiatan dakwah, Pembedanya terletak pada isi dan tujuan kegiatan dakwah dan kegiatan komunikasi. Pada komunikasi isi pesannya umum sehingga bisa juga berupa ajaran agama, sementara orientasi pesannya adalah pada pencapaian tujuan dari komunikasi itu sendiri, yaitu adanya efek dan hasil berupa perubahan pada komunikan. Sedangkan pada dakwah isi pesannya jelas berupa ajaran Islam dan tujuannya adalah penggunaan metode yang benar menurut ajaran dan nilai-nilai Islam. Dakwah merupakan komunikasi ajaran-ajaran Islam dari seorang da'i kepada umat manusia dikarenakan didalamnya terjadi proses komunikasi.

\section{Paham Radikalisme}

Istilah radikalisme ini semakin marak dibicarakan di Indonesia. Menurut Sudjana, "radikalisme merupakan sikap atau tindakan terhadap berbagai perubahan tatanan kehidupan yang sudah lama dan mapan (established)." (Sudjana, Eggi, 2008:100). Selanjutnya, Sayyid Thanthawi menyebutkan bahwa orang yang radikal (mutatharrif) sebagai orang yang melampaui batas-batas syar'iyah dalam hal apapun sampai dalam hal ibadahnya. Lebih lanjut Yusuf Qardhawi mengemukakan bahwa penyebab dari radikalisme adalah fanatisme (taashub) pendapat, tidak mau mengakui pendapat lain. Indikasinya adalah kaum radikalis kasar dalam berdakwah berburuk sangka (su'udzan) terhadap orang lain. Radikalisme mencapai puncaknya jika orang yang radikal tersebut dapat menjatuhkan kehormatan pihak lain, menghalalkan harta dan darah mereka.(Ath-Thahhan, 2000:191)

\section{Media Sosial}

Menurut Shirky (2008), media sosial dan perangkat lunak sosial merupakan alat untuk meningkatkan kemampuan pengguna untuk berbagi (to share), bekerja sama (to co-operate) diantara pengguna dan melakukan tindakan secara kolektif yang semuanya berada di luar kerangka institusional maupun organisasi. Boyd (2009) menjelaskan media sosial sebagai kumpulan perangkat lunak yang memungkinkan individu maupun komunitas 
untuk berkumpul, berbagi, berkomunikasi,dan dalam kasus tertentu saling berkolaborasi atau bermain. Media sosial memiliki kekuatan pada user-generated content (UGC) di mana konten dihasilkan oleh pengguna, bukan oleh editor sebagaimana di institusi media sosial. Menurut Van Dijk (2013), media sosial adalah platform media yang memfokuskan pada eksitensi pengguna yang memfasilitasi mereka dalam beraktivitas maupun berkolaborasi, Karen itu, media sosial dapat dilihat sebagai medium (fasilitator) online yang menguatkan hubungan antarpengguna sekaligus sebagai sebuah ikatan sosial. (Nasrullah, Rulli, 2017 : 11).

\section{Metode Penelitian}

Pendekatan yang digunakan dalam penelitian ini adalah mix-methods. Penelitian akan diawali dengan pendekatan kuantitatif dan selanjutnya dianalisis dengan pendekatan kualitatif. Creswell (2014: 5) menjelaskan bahwa mix- methods merupakan “...pendekatan penelitian yang mengkombinasikan atau mengasosiasikan bentuk kualitatif dan kuantitatif". Dengan desain penelitian eksplorasi yang diikuti dengan studi kasus. Penelitian eksploratif (explorative research) adalah jenis penelitian yang bertujuan untuk menemukan suatu pengetahuan baru yang sebelumnya belum ada.

Sampel pada penelitian kualitatif disebut informan, responden atau nara sumber, yaitu orang-orang yang dipilih untuk diwawancarai atau diobservasi sesuai tujuan riset. Disebut responden karena informan dianggap aktif mengkonstruksi realitas, bukan hanya sekedar objek yang hanya mengisi kuisioner (Kriyantono, 2008). Disini subjek akan dipilih secara purposif sesuai dengan keperluan penelitian.

Informan yang dipilih adalah mahasiswa Komunikasi dan Penyiaran Islam IAIN Syekh Nurjati Cirebon. Pemilihan mahasiswa dapat lebih dipersempit ruang lingkupnya pada para mahasiswa yang mengikuti organisasi intra kampus, khususnya organisasi Lembaga Dakwah kampus (LDK)

\section{Hasil Dan Pembahasan}

Survey Alvara Research Center dan Mata Air Foundation menunjukkan angka yang mengkhawatirkan. 23, \% mahasiswa setuju dengan jihad untuk tegaknya negara Islamatau khilafah.Mendekati angka tersebut, 23,3\% pelajar SMA sederajatjuga menyetujui wacana pendirian negara Islam. Sebanding dengan wacana tersebut, $18,1 \%$ pegawai swasta menyatakan ketidaksetujuannya dengan ideologi Pancasila. Hal ini juga diamini oleh sekitar 19,4\% pegawai negeri sipil, dan 9,1\% pegawai BUMN memiliki pandangan yang sama terkait dengan ideologi Pancasila. Lembaga Alvara Research Center melakukan survey tentang menguatnya gerakan radikalisme di Indonesia. Hasil survei yang dilakukan pada pertengahan Oktober 2017 lalu ini menimbulkan kekhawatiran terkait dampak penyebaran paham radikal yang sudah menyasar hingga ke lapisan masyarakat paling bawah.

Terlepas dari validitas hasil survey 
tersebut, pemerintah berupaya untuk seera mengantisipasi perkembangan paham radikalisme terkhusus pada dunia pendidikan. Angka yang ditunjukkan oleh survey tersebut cukup mengkhawatirkan sehingga pemerintah memutuskan untuk memberikan perhatian serius pada masalah radikalisme yang berkembang di dunia pendidikan, khususnya pendidikan tinggi.

Badan Nasional Penanggulangan Teroris (BNPT) bahkan secara khusus memberikan perhatian yang lebih kepada generasi muda ini. Berbagai poster, imbauan bahkan seminar dilakukan untuk meredam penyebaran dan pertumbuhan paham radikalisme di kalangan mahasiswa. Dengan berbagai kebijakannya, seperti seminar nasional, pengumpulan para rektor terkait radikalisme serta usulan pengawasan atas nomor handphone serta account media sosial digulirkan untuk meredam penyebaran dan pertumbuhan paham radikalisme di kalangan mahasiswa.

Dalam beberapa kesempatan, BNPT memberikan penyuluhan dan seminar kepada kalangan civitas akademia. Bahkan BNPT menyebarluaskan poster, baik di dunia nyata maupun dalam website dan dunia maya terkait dengan karakteristik organisasi kemahasiswaan yang ditengarai terpapar paham radikalisme. Sebagaimana tersebar di dunia maya, BNPT menyebutkan beberapa karakteristik organisasi (mahasiswa) yang telah terpapar dan diindikasikan terpengaruh oleh paham radikalisme. Karakteristik tersebut antara lain, tertutup dan tidak mau terbuka pada pandangan lain, apalagi bagi kalangan yang berbeda keyakinan; mudah mengkafirkan orang lain, bahkan sesama muslim; ingin menegakkan hukum agama menggantikan dasar negara yang dipandang thogut atau pemerintahan yang kafir; menempatkan barat secara ideologis-politis sebagai ancaman terhadap kesatuan umat; mengajak keanggotaan, melaksanakan kajian diskusi secara tertutup,bahkan harus mengadakan pembaitan; sebagian mengambil cara non-kekerasan (radikal gagasan), sebagian lain mengambil cara kekerasan (radikal terorisme). Demikian sebagaimana dikutip oleh website damailah indonesiaku.com dari https://twitter.com/bnptri/status/860407566538 481 664. Hampir mirip dengan karaketristik yang disebutkan oleh BNPT, dalam website https://pinterpolitik.com/kelompok-radikal-kua sai-kampus/ juga menyebutkan beberapa ciri atau karakteristik tersebut.

Pada sisi lain, mahasiswa Jurusan Komunikasi dan Penyiaran Islam (KPI) Fakultas Ushuluddin, Adab dan Dakwah,Institut Agama Islam Negeri (IAIN) Syekh Nurjati Cirebon mengetahui dan menyadari adanya terpaan materi radikalisme. Sebagaimana generasi netizen, mahasiswa KPI telah terbiasa dengan smartphone. Bahkan ada mahasiswa yang memiliki lebih dari satu buah. Demikian pula dengan keaktifan mereka di media sosial. Kebanyakan dari mereka telah memiliki minimal satu email dan satu account di media sosial, baik Facebook, twitter dan sejenisnya.

Dengan durasi penggunaan 
smartphone yang relatif tinggi, mahasiswa KPIpernh mencoba mencari informasi terkait dengan paham radikalisme. Berbeda dengan mahasiswa lainnya, mahasiswa KPI hanya sekilas saja mengakses website atau situs-situs yang bermuatan radikalisme. Setelah mereka menganggap informasi yang ingin diketahuinya tercapai,maka mereka secara aktif dan sadar meninggalkan website atau situs-situs bermuatan radikalisme tersebut. Hampir tidak ada mahasiswa KPI yang mengakses website atau situs yang sama di kemudian hari. Adapun jumlah website atau situs yang diakses sangat sedikit dikarenakan menurut mahasiswa KPI materi yang ada secara umum memiliki kesamaan.

Dalam kegiatan di media sosial, mahasiswa KPI cenderung tidak terlalu aktif berdiskusi terkait permasalahan radikalisme. Ketika ada salah seorang yang membuka diskusi online tentang hal-hal yang memiliki konotasi radikalisme maka mahasiswa KPI hanya sebagai penyimak pasif. Mahasiswa KPI tidak berminat untuk turut menyampaikan pendapatnya terkait dengan paham radikalisme.

Dengan adanya himbauan dari BNPT, IAIN Syekh Nurjati Cirebon secara aktif melaksanakan kegiatan-kegiatan yang mencoba meredam penyebaran dan pertumbuhan paham radikalisme. Salah satu kegiatan tersebut adalah kegiatan yang dilakukan pada bulan Juni 2018 yaitu sosialisasi 'Penangkalan Gerakan Radikalisme Serta Ancaman Terhadap Pancasila dan NKRI di Kalangan Mahasiswa di Lingkungan IAIN Syekh Nurjati Cirebon`. Kegiatan yang dihadiri oleh seluruh unit kegiatan mahasiswa (UKM) di lingkungan IAIN Syekh Nurjati Cirebon untuk diberikan pemahaman tentang gerakan radikalisme dan ancaman terhadap NKRI. Sosialisasi ini dilakukan untuk mencegah lebih dini menyebarnyyang dilakukan oleh organisasi a paham radikalisme di lingkungan IAIN Syekh Nurjati Cirebon.

Selain kegiatan sosialisasi tersebut, melalui Wakil rektor III Bidang Kemahasiswaan, IAIN Syekh Nurjati Cirebon juga menitipkan pesan guna menyebarluaskan materi deradikalisme kepada seluruh UKM yang berada di lingkungan IAIN Syekh Nurjati Cirebon. Bahkan tidak hanya UKM yang berada di internal kampus, organisasi kemahasiswaan di luar kampus pun dihimbau untukmemberikan pemahaman tentang bahaya radikalisme pada setiap kegiatan yang mereka laksanakan.

\section{Simpulan}

Berdasarkan temuan hasil penelitian di lapangan, secara umum peneliti dalam penelitian ini dapat menyimpulkan bahwa mahasiswa Jurusan Komunikasi dan Penyiaran Islam telah memiliki kesadaran dalam menggunakan smartphone dalam mengakses media sosial terkait aksesitas website-website yang diduga mengandung materi/konten radikalisme.

Sedangkan kesimpulan secara khusus adalah sebagai berikut:

1. Secara demografis serta preferensi 
media, mahasiswa tergolong dalam usia produktif yang masih aktif mencari jati diri dan smartphone untuk bermedia sosial merupakan salah satu media pencarian jati diri

2. Smartphone merupakan media untuk mengakses media sosial oleh mahasiswa dan pola penggunaan media sosial dalam penelusuran materi radikalisme tidak berperan dalam penyerapan ide-ide radikalisme di kalangan mahasiswa.

Berdasarkan hasil temuan penelitian dan kesimpulan, maka peneliti menyarankan beberapa hal, yaitu,

1. Penelitian ini masih belum mengkaji tentang efektivitas media sosial dalam menyebarluaskan paham radikalisme di kalangan mahasiswasehingga perlu ada peneltian lanjutan terkait permasalahan ini.

2. Efektivitas kegiatan deradikalisme yang dilakukan baik oleh pihak internal kampus maupun pihak luar kampus seperti BNPT (Badan Nasional Penanggulangan Terorisme) maupun organisasi agama kemasyarakatan belum terdatadengan baik sehingga diperlukan penelitian lanjutan untukmengetahui efektivitas kegiatan deradikalisme khususnyadi kalangan mahasiswa, baik di dalam maupun di luar kampus

3. Output penelitian berupa artikel ilmiah dapat dipergunakan sebagai bahan kajian selanjutnya bagi pengembangan metode deradikalisme baik di kalangan mahasiswa maupun dikalangan masyarakat umum.

4. Pendidikan literasi terkait paham radikalisme perlu ditingkatkan baiksecara formalatau dimasukkan dalam kajian kurikulum maupun secara non-formalmelalui berbagai kegiatan kemahasiswaan.

\subsection{Ucapan Terimakasih}

Kami mengucapkan terima kasih kepada Jurusan Bimbingan dan Konseling Islam serta Jurusan Komunikasi dan Penyiaran Islam, Lembaga Penelitian dan Pengabdian kepada Masyarakat (LPPM), dan Fakultas Ushuluddin, Adab dan Dakwah Insttut Agama Islam Negeri (IAIN) Syekh Nurjati Cirebon, Kementerian Agama RI yang telah memberikan kesempatan untuk melaksanakan penelitian serta memberikan bantuan dana penelitian berdasarkan DIPA tahun 2018 .

Begitu pun kepada rekan-rekan dosen, dan mahasiswa peneliti mengucapkan terima kasih atas bantuan dan dukungannya bagi terlaksananya penelitian ini. Tidak lupa juga ucapan terimakasih disampaikan kepada mahasiswa Jurusan Komunikasi dan Penyiaran Islam IAIN Cirebon yang telah mendukung pelaksanaan penelitian ini dengan proporsional.

\section{Daftar Pustaka}

Achmad, Amrullah (edit). 1983. Dakwah 
Islam dan Perubahan

Sosial.Yogyakarta.: PLP2M.

Amin, Samsul Munir. 2009. Ilmu Dakwah. Jakarta: Amzah.

Amirsyah. 2012. Meluruskan Salah Paham terhadap Deradikalisme : Pemikiran, Konsep dan Strategi pelaksanaan. Jakarta : Grafindo Khazanah ilmu dan Sentra HAKI, UMJ

Andriadi, Fayakhun. 2017. Partisipasi Virtual : Demokrasi Netizen di Indonesia. Jakarta :RMBOOKS

Arifianto S. 2018. Praktik Budaya Media Digital dan Pengaruhnya. Yogyakarta : Aswaja Pressindo.

Asari, Akhmad Fauzi, dik. 2016. Radikalisme Islam di Kalangan Mahasiswa Perguruan Tinggi Negeri di Banjarmasin. Banjarmasin : IAIN Antasari Press.

Creswell, John. 2014. Research Design Pendekatan Kualitatif, Kuantitatif, dan Mixed. Yogyakarta: Pustaka Pelajar.

Ibrahim, Idi Subandy dan Iriantara, Yosal. 2017. Komunikasi yang Mengubah Dunia: Revolusi dari Aksara hingga Media Sosial. Bandung : Simbiosa Rekatama Media.

Nasrullah,Rulli.2017. Media Sosial : Perspektif Komunikasi, Budaya dan Sosioteknologi. Bandung : Remaja Rosdakarya.

Nurudin. 2017. Perkembangan Teknologi Komunikasi. Jakarta : RajaGrafindo Persada.

Rogers, Everett M. 1986. Communication Technology:The New Media in Society. New York : The Free Press.

Schmidt, Eric dan Cohen, Jared. 2014. The New Digital Age. Jakarta : Kepustakaan Populer Gramedia.

Sugihartati, Rahma. 2014. Perkembangan
Masyarakat Informasi da Teori Sosial Kontemporer. Jakarta : Kencana.

Supandi. 2013. Psikologi : Anak-Anak Pelaku Tindak Pidana Terorisme di Indonesia. Ciputat : PUSTIKOM.

Turmudi, Endang dan Sihbudi, Riza. 2005. Islam dan Radikalisme di Indonesia. Jakarta : LIPI Press.

Orasi: Jurnal Dakwah dan Komunikasi | Volume 10, No. 2, Desember 2019 